DOI: http://dx.doi.org/10.24093/awejtls/vol1no3.4

\title{
The Translatability of Schemata in the Holy Quran: Seeing the Invisible
}

\author{
Adnan Abumahfouz \\ Salt College for Human Sciences, Al-Balqa Applied University \\ Salt, Jordan \\ Yasser Al-shboul \\ Salt College for Human Sciences, Al-Balqa Applied University \\ Salt, Jordan
}

\begin{abstract}
This paper investigates the correctness and accuracy of some translations of the meanings of the Holy Quran in echoing the schemata of some Quranic terms. It also examines the amount of translation loss resulting from this process. Moreover, the paper highlights some reasons which made translators of the meanings of the Holy Quran lose sight of part of the culture-bound, culture sensitive and language-bound schemata. Euphemism and synonymy, however, were addressed in so far as schemata are concerned. The paper also endeavors to suggest solutions, when possible, to make up for the amount of translation loss resulting from the formal or functional equivalence opted for by many translators of the meanings of the Holy Quran which led to the activation of slightly, and sometimes utterly, different schemata. However, the translation loss is inevitable in many cases. The findings of the present paper are expected to be useful information in the translation of the meanings of the Holy Quran studies and other related areas. Three prominent translations of the meanings of Holy Quran (Abdullah Ali, Pickthall, and Al-Hilali and Khan) were consulted and resorted to tackle the main premise of the study along with one commendable Qur'anic exegesis (Ibn Katheer).
\end{abstract}

Keywords: culture-bound, functional equivalence, schemata, The Holy Quran, translation loss

Cite as: Abumahfouz, A., \& Al-shboul, Y. (2017). The Translatability of Schemata in the Holy Quran: Seeing the Invisible. Arab World English Journal for Translation \& Literary Studies, 1(2). DOI: http://dx.doi.org/10.24093/awejtls/vol1no3.4 